\title{
DENSITY OF LOCATION OF THE EASTERN FRESHWATER SHRIMPS (MACROBRANCHIUM NIPPONENSE DE HAAN, 1849) IN THE LOWER RIVER BASIN DNISTER
}

\section{P. Shekk, shekk@ukr.net, Odessa State Environmental University, Odessa Yu. Astafurov, astafurov.yu@ukr.net, Odessa State Environmental University, Odessa}

Purpose. To investigate the distribution of Macrobrachium nipponense in the Dniester river basin in the south of Ukraine. To assess their density and diurnal fluctuations and determine their sex ratios in different waters.

Methodology. Shrimps were caught using crayfish traps of original design with a length of 50-

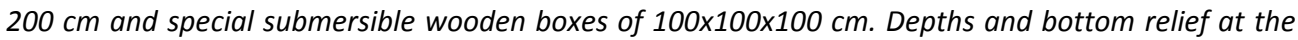
study sites were determined using a Garmin EchoMAP CHIRP 72sv. The location was established using a GPS unit Garmin gpsmap 78s and Google Maps 2D. The sample size was 4687 individuals, 88 locations of shrimp aggragations were detected. The diurnal population dynamics was studied at 7 sites. Sex and sex ratio of sampled shrimps where determined using a standard biological analysis.

Findings. The analysis of litertures sources showed the pathways of the spread of $M$. nipponense across the territory of the republics of the USSR and the history of its acclimatization in the Dniester River. The currents shrimp stock density and their sex ratios in different water bodis of the lower Dniester were determined. The diurnal dynamics of changes in shrimp populations was studied at different sites in the Dniester and Kuchurgan lagoons. It was found that the local populations of shrimp from different waters differ significantly in terms of their numbers and sex ratios. The circadian dynamics of shrimp population density in the Dniester and Kuchurgan lagoons had a similar character but differed in absolute numbers.

Originality. The distribution of $M$. nipponense in the lower reaches of the Dniester was studied for the first time. The abundance of this shrimp in different waters and their sex ratio were established. The circadian dynamics of population changes in the Dniester and Kuchurgan estuaries was studied.

Practical value. The results of the study allowed obtaining an objective biological-geographical characteristic of M. nipponense in the conditions of the Lower Dniester basin. The obtained results can be used to assess the state of the natural population of M. nipponense in the lower Dniester and to determine the prospects of its use as an object of domestic fish farming and aquaculture.

Key words: Shrimp, M. nipponense, Lower Dniester, introduction, natural population, density, sex differences.

\section{ИССЛЕДОВАНИЯ ПЛОТНОСТИ СКОПЛЕНИЙ ВОСТОЧНОЙ ПРЕСНОВОДНОЙ КРЕВЕТКИ (MACROBRANCHIUM NIPPONENSE DE HAAN, 1849) В БАССЕЙНЕ НИЖНЕГО ДНЕСТРА}

П. В. Шекк, shekk@ukr.net, Одесский государственный экологический университет, г. Одесса

Ю. А. Астафуров, astafurov.yu@ukr.net, Одесский государственный экологический университет, г. Одесса

C P. Shekk, Yu. Astafurov, 2020 
Цель работы. Исследовать распространение Macrobrachium nipponense на территории юга Украины в бассейне нижнего Днестра. Оценить плотность креветки и ее суточные колебания, установить соотношение ото к $о$ о различных акваториях.

Методика. Для отлова креветок использовали ловушки типа раколовки длиной от 50200 см оригинальной конструкции и специальные погружные деревянные короба размером $100 \times 100 \times 100$ см. Глубины и рельеф дна в местах проведения исследований определяли $c$ помощью эхолота Garmin EchoMAP CHIRP 72sv. Локацию устанавливали с помощью спутникового GPS навигатора garmin gpsmap 78s u google maps 2d. Объем выборки составила 4687 экз. креветок, установлено 88 локаций скоплений креветок. Суточную динамику численности изучали на 7 стационарных станциях. При проведении стандартного биологического анализа у креветок определяли: пол, и соотношение оㅇк $\$$.

Результаты. На основе анализа литературных источников установлены пути распространения креветок М. пірропеnse на территории республик СССР и историю акклиматизации ее в р. Днестр. Определена современная плотность креветки и соотношение полов в различных акваториях нижнего Днестра. На стационарных станциях в Днестровском и Кучурганском лиманах исследовалась суточная динамика изменений численности креветки. Установлено, что по показателям численности и соотношения о“б" фо локальные популяции креветки с разных акваторий значительно различаются. Церкадная динамика плотности популяций креветки в Днестровском и Кучурганском лиманах имела сходный характер но отличалась по абсолютным показателям.

Научная новизна. Впервые исследовано распространение интродуценты - креветки М. nipponen в низовьях Днестра. Установлено численность креветки в различных акваториях и соотношение от" и фо. Иследована циркадная динамика изменений численности в Днестровском и Кучурганском лиманах.

Практическая значимость. Результаты исследований позволили дать объективную эколого-биологическую характеристику M. nipponense в условиях бассейна нижнего Днестра. Полученные результаты могут быть использованы для оценки состояния природной популяции М. nipponense нижнего Днестра и определения перспектив ее использовании в качестве объекта отечественного рыбоводства и аквакультуры.

Ключевые слова: Креветка, М. nipponense, нижний Днестр, интродукция, естественная популяция, плотность, половое соотношение.

\title{
ДОСЛІДЖЕННЯ ЩІЛЬНОСТЕЙ СКУПЧЕННЯ СХІДНОЇ ПРІСНОВОДНОÏ КРЕВЕТКИ (MACROBRANCHIUM NIPPONENSE DE HAAN, 1849) В БАСЕЙНІ НИЖНЬОГО ДНІСТРА
}

\author{
П. В. Шекк, shekk@ukr.net, Одеський державний екологічний університет, \\ м. Одеса \\ Ю. О. Астафуров, astafurov.yu@ukr.net, Одеський державний екологічний \\ університет, м. Одеса
}

Mema. Дослідити поширення Macrobrachium nipponense на території півдня України у басейні нижнього Дністра. Оцінити щільність креветки та ії добові коливання, встановити співідношення о“о"до о० в різних акваторіях.

Методика. Для вилову креветок використовували пастки типу раколовки довжиною від 50-200 см оригінальної конструкції та спеціальні погружні дерев'яні короби розміром 100×100×100 см. Глибини та рельєф дна в місцях проведення досліджень визначали за допомогою ехолота Garmin EchoMAP CHIRP 72sv. Локацію встановлювали за допомогою супутникового GPS навігатора garmin gpsmap 78s ma google maps 2 . Обсяг вибірки становил 4687 екз. креветки, встановлено 88 локачій скупчення креветок. Добову динаміку 
чисельності вивчали на 7 стаціонарних станціях. При проведенні стандартного біологічного аналізу у креветок визначали: стать, та співідношення о о" до $q 9$.

Результати. На основі аналізу літературних джерел встановлені иляхи розповсюдження креветок М. пірроnense на теріторії республік колишенього СРСР, історія акліматизації ї̈ в р. Дністер.

Визначена сучасна щільність креветки та співвідношення статей в різних акваторіях нижнього Дністра. На стаціонарних станціях у Дністровському та Кучурганському лиманах досліджувалась добова динаміка змін чисельності креветки. Встановлено, що за показниками чисельності та співвідношення о“о̆ $і$ оЯ локальні популяції креветки з різних акваторій значно різняться. Церкадна динаміка щільності популяцій креветки у Дністровському та Кучурганському лиманах мала схожий характер але відрізнялась за абсолютними показниками.

Наукова новизна. Вперше досліджено розповсюдження інтродуценти - креветки М. nipponen в пониззі Дністра. Встановлено чисельність креветки в різних акваторіях та співвідношення о“o"i о․ Виявлена циркадна динаміка змін чисельності у Дністровському та Кучурганському лиманах.

Практична значимість. Результати досліджень дозволили дати об'єктивну екологобіологічну характеристику М. пірропепsе в умовах басейну нижнього Дністра. Отримані результати можуть бути використані для оцінки стану природної популяції M. пірроnense нижнього Дністра та визначення перспектив ії використання як об'єкту вітчизняного рибництва та аквакультури.

Ключові слова: Креветка, М. пірропепsе, нижній Дністер, інтродукція, природна популяція, щільність, статеве співвідношення.

\section{PROBLEM STATEMENT AND ANALYSIS OF LATEST RESEARCH AND PUBLICATIONS}

Since the beginning of the twentieth century the problem of biological invasions of alien species has become more acute, and there has been a significant increase in alien species in areas quite far from their natural ranges. This phenomenon is global and significantly affected aquatic ecosystems, including those that belong to the Black Sea catchment, where the number of new species of flora and fauna has increased in recent decades $[7,12]$.

In autumn 2013, several specimens of M. nipponense were caught in a crayfish trap in the Dniester River near Tiraspol by a student of the Faculty of Geography of the Taras Shevchenko Transnistrian State University. Thus, 27 years after the introduction of this species into the Kuchurgan reservoir, it was able to: acclimatize in the reservoir, adapt to low temperatures, establish a stable natural population capable of effective reproduction, penetrate into the Turunchuk Strait where it spread upstream, penetrated into the Dniester River reaching Tiraspol [12].

According to Google Maps, the distance covered by this shrimp from the Kuchurgan Reservoir to Tiraspol was about $70 \mathrm{~km}$ or $2.5 \mathrm{~km}$ per year $[12,15]$.

In July and August 2013, Odessa scientists Stepanko N. and Gubanov V. identified shrimp M. nipponens in the Dniester lagoon during the sampling of benthic fauna in the waters of the Dniester estuary near the village Nikolaevka. The shrimps sampled were two females with eggs. Sampling was carried out with a net with a mesh size of $10 \mathrm{~mm}$ on the coastal area with muddy bottom. Later, in the northern part of the Karagol Bay, rangers of the State Protection Service of the Lower Dniester National Nature Park 
found another 6 specimens in poachers' traps (mesh size of 18-20 mm). Forty eight individuals of $M$. nipponens of different age groups including one egg-laden female were caught in a fish pond near the village Mayaki at a depth of $0.5 \mathrm{~m}$ [11].

Interviewing of local fishermen confirmed the presence of M. nipponens in the Dniester and Turunchuk rivers [11, 12, 14].

In 2016, Head of the Department of Aquatic Bioresources and Aquaculture, Odessa State Ecological University Shekk P. and junior research scientist (graduate student) of the Department of Aquatic Bioresources and Aquaculture of Odessa State Ecological University Astafurov Yu. initiated complex works on the study of the distribution of $M$. nipponens in the lower reaches of the Dniester River $[14,15]$.

The area of the lower Dniester as a whole is interesting by very drastic and rapid changes in the environmental conditions for a short period of time starting from 1986. Thus, the interaction of "biogeography" with the practice regarding the problem of biotic invasions is necessary $[11,14]$.

The importance of the topic is enhanced by the fact that works in this area is actively carried out in the United States, Britain, Sweden, France, Australia and other countries. In Ukraine, such studies have not been conducted systematically, and the materials available in the literature are fragmentary and incomplete and require analysis and generalization. This is necessary to initiate more detailed studies in this direction [5, $13]$.

\section{SELECTION OF UNRESOLVED PARTS GENERAL PROBLEM. THE PURPOSE OF THE WORK}

To date, the study of the distribution of M. nipponens in the lower Dniester has not been conducted. There are only fragmentary data on the occurrence of individual shrimp in different waters. The formation of M. nipponens aggregations, their density and sex ratio in the Dniester river basin has also not been studied.

\section{MATERIALS AND METHODS}

The study was conducted from 2016-2019 on coastal sites of the Dniester River in lagoons and lakes. M. nipponens were caught with crayfish traps of original design with a length of 50-200 cm and special submersible wooden boxes of 100x100x100 cm. Depths and relief of the bottom at the sampling sites were determined using a Garmin EchoMAP CHIRP 72sv. The standard biological analysis of shrimps included the determination of their sex and sex ratio. In total, 4687 specimens were analyzed. shrimp, 88 locations of shrimp aggregations were established. Monthly continuous observations were performed at 7 sites.

Species identification of shrimps was performed using the appropriate identification keys $[2,10]$. The location was recorded using a GPS navigator Garmin Gpsmap 78s. Statistical data processing was performed in Microsoft Excel.

\section{RESEARCH RESULTS AND DISCUSSION}

M. nipponense were found in brackish waters of estuaries, lagoons, along sea coasts, as well as at great distances from the sea: rivers with large amounts of aquatic vegetation with sandy or muddy bottoms $[6,16,17,18]$. 
The native range of $M$. nipponense covers China, Japan, Korea, Vietnam, Myanmar and Taiwan. As a promising object of aquaculture, it was introduced into the water bodies of Singapore, Philippines, USA, Israel, Iraq, Iran, India, the republics of the former USSR (Russia, Belarus, Moldova, Kazakhstan, Tajikistan) and other countries [1, 4 6, 8, 19, 20, 21, 22] (Fig. 1).

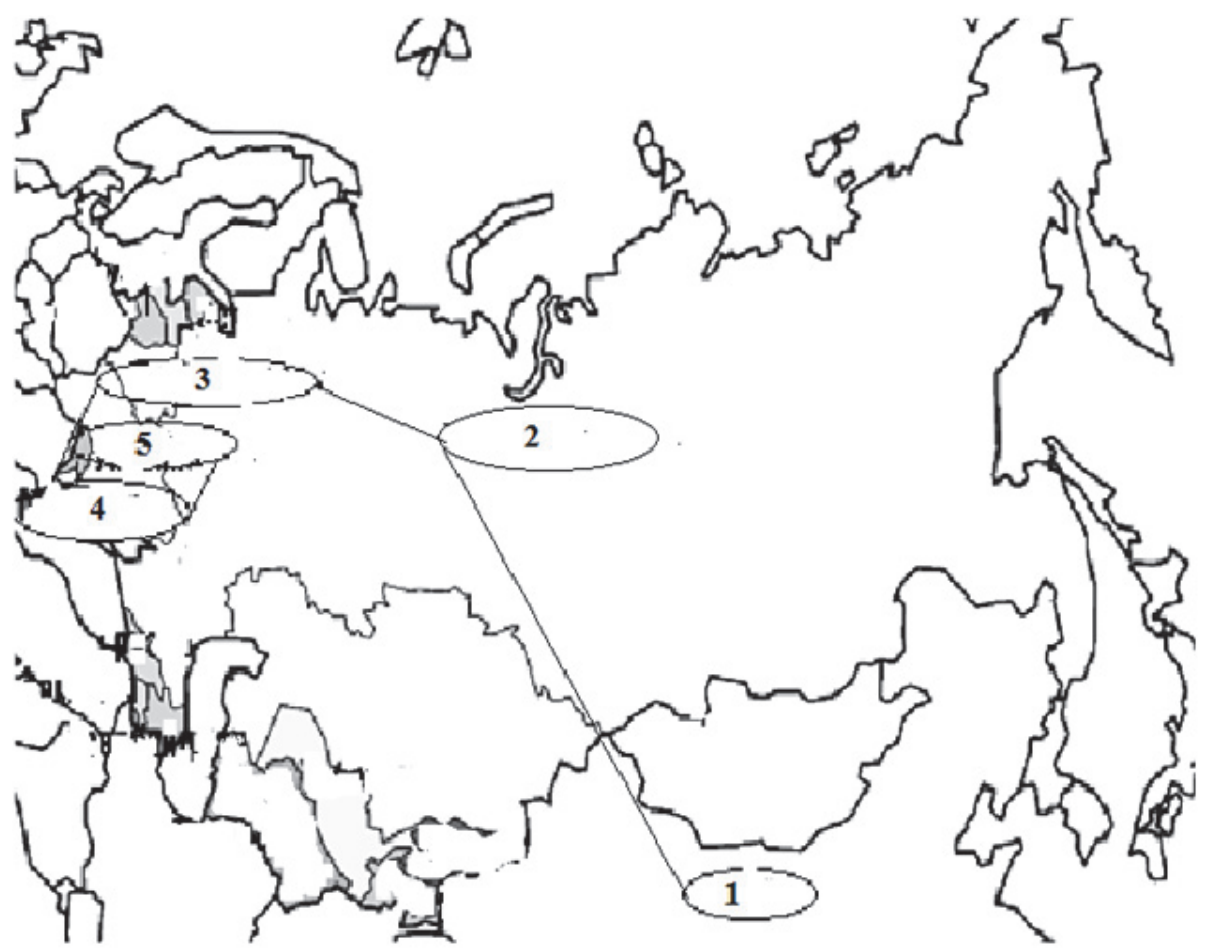

Fig. 1. Introductory shrimp scheme M. nipponense from China - 1 to Russia 2, Belarus - 3, Pridnistrov'ya (Moldova) - 4 and Ukraine - 5

M. nipponense was introduced into the Kuchurgan Reservoir from the Berezovskaya GRES reservoir. The stocking density of $M$. nipponense in the reservoir in 1986 was about 2 ind./ha and this was enough to obtain a positive effect of acclimatization [3].

Since the end of 1987, the population abundance in the reservoir was assessed as 0.6 million individuals, and it increased to almost 1.5 million individuals in 1988. Due to favorable ecological conditions, the growth rate of this shrimp in the Kuchurgan Reservoir was higher than in the parent reservoirs of Southeast Asia and the cooling reservoirs of the Berezovskaya GRES [3, 7, 9, 12].

The population of freshwater shrimp in the Kuchurgan reservoir was dominated by males. The shrimp population in the reservoir showed high potential reproductive capacity (fertility), which also contributed to the successful naturalization of the species $[3,7,11,12]$. 


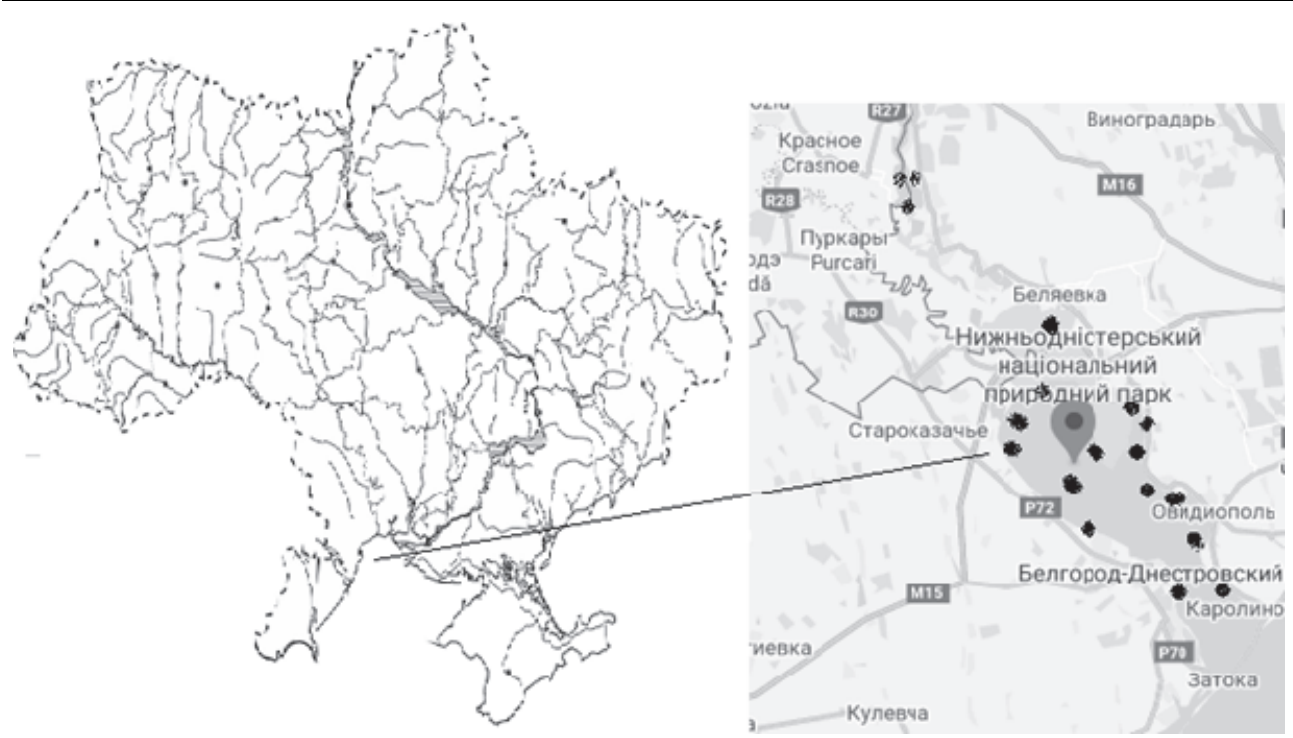

Fig. 2. Locations of $M$. nipponense sampling sites in the lower reaches of the

\section{Dniester River.}

The locations of $M$. nipponense shrimp in different waters of the Lower Dniester were determined from the shores, bridges and boats using a GPS navigator.

The highest abundance of $M$. nipponense was recorded in the Dniester lagoon (coordinates 46.209311, 30.7742). The density of shrimp per $1 \mathrm{~m}^{2}$ here reached 17 individuals $\cdot \mathrm{m}^{-2}$. Males predominated in the aggregations (sex ratio - 11: 6). The minimum density of shrimp (2.2 individuals $\cdot \mathrm{m}^{-2}$ ) was observed in the Bile Lake (coordinates 46.447324, 30.187776). The sex ratio here was 1: 1 (Fig. 3).

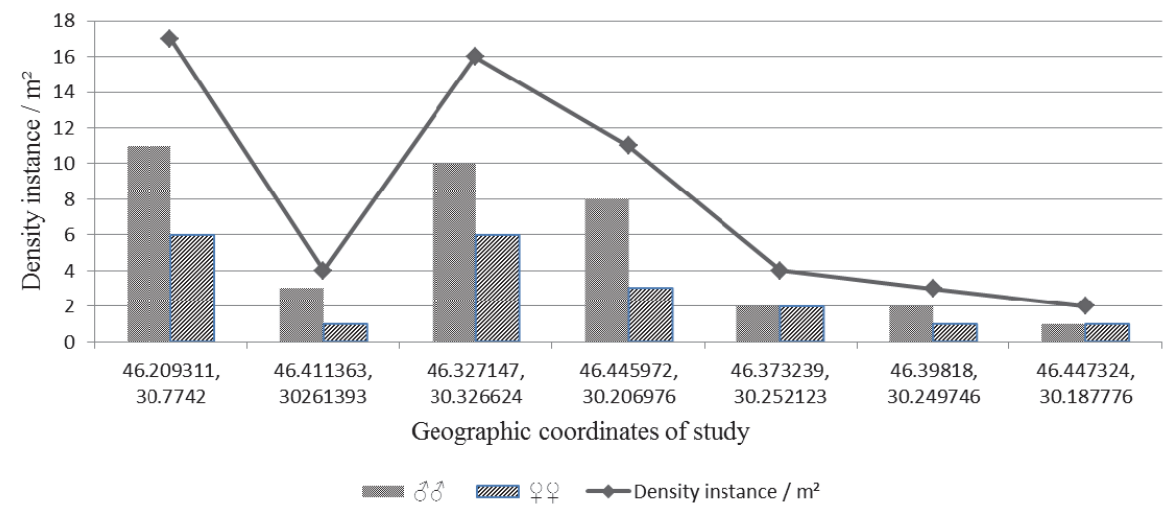

Fig. 3. Sex ratio and the density of $M$. nipponense in the water bodies of the lower Dniester

The density of shrimps in some water bodies of the lower Dniester varied significantly (4-9 times) during the day. The largest fluctuations in the numbers of shrimp were observed in the Dniester lagoon (coordinates 46.209311, 30.7742) and Kuchurgan lagoon (coordinates 46.636726, 29.957984). On-site observations at these 
two stations showed that the number of shrimp in the Dniester lagoon was higher than in the Kuchargan lagoon (Fig. 4).

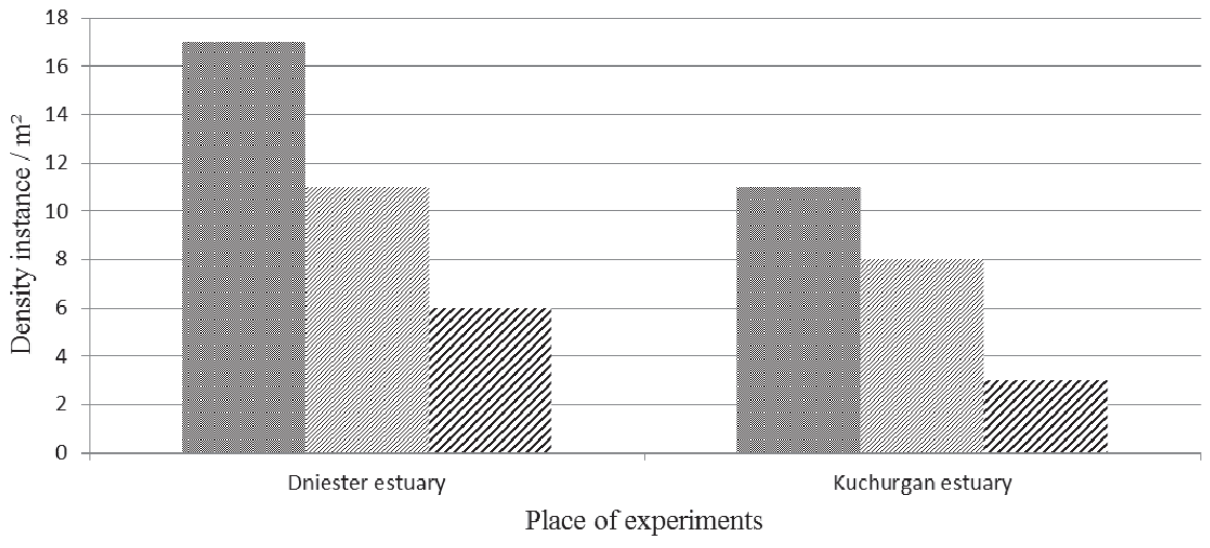

Density instance $/ \mathrm{m}^{2}$ 绻 80

Fig. 4. Density and sex ratio of $M$. nipponense articles at two sampling sites in the Dniester and Kuchurgan lagoons.

Such a population structure may indicate more favorable conditions for $M$. nipponense that have developed currently in the Dniester estuary.

It was found that the density of $M$. nipponense changed significantly during a day. A study of the dynamics of the abundance and density of shrimps at sampling sites in the Dniester and Kuchurgan lagoons showed that the diurnal fluctuations in their abundances had similar dynamics. The maximum abundance of shrimps was observed at four o'clock in the morning, gradually decreasing to 9 o'clock, followed by a sharp drop from 9 to 12 o'clock. In the next period from 12 to 24 hours, the density of shrimps was at a minimum, relatively stable level. From 1 o'clock at night there was a gradual increase in the number of shrimps to a maximum at four o'clock in the morning. It should be noted that this process was more dynamic in the Dniester lagoon and the fluctuations were more significant than in the Kuchurgan lagoon (Fig. 5).

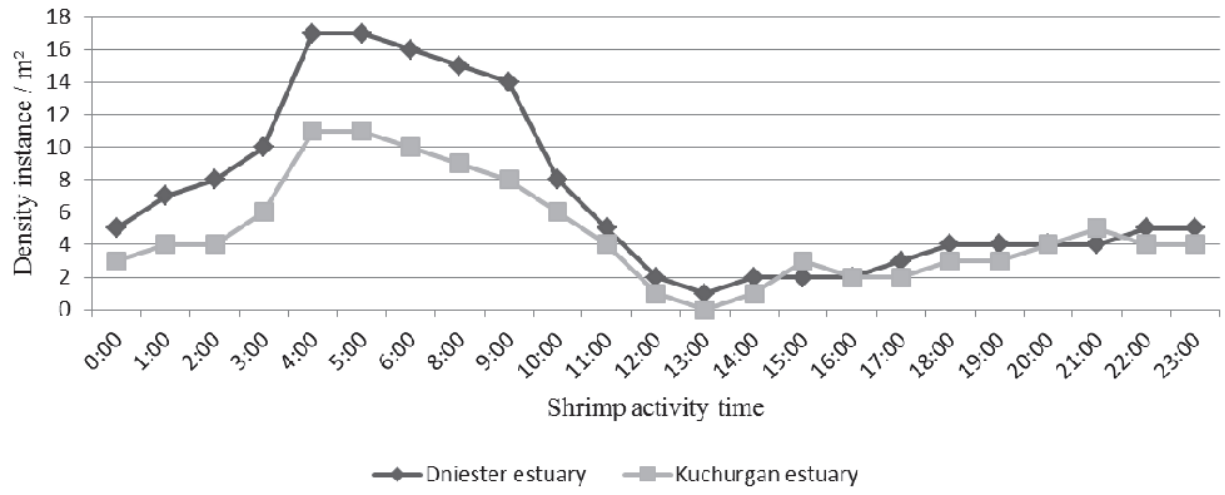

Fig. 5. Diurnal dynamics of $M$. nipponense density in open areas of Dniester and Kuchurgan lagoons (sampling sites) 


\section{CONCLUSIONS AND PROSPECTS FOR FURTHER DEVELOPMENT}

The rapid development of the world economy is a powerful anthropogenic factor that affects the distribution of plants and animals in terrestrial and aquatic ecosystems. Directed acclimatization and unauthorized introduction of organisms often leads to reversible, or more often, irreversible changes in biocenoses. The results of such changes require careful studies and evaluation.

M. nipponense, which penetrated into the Kuchurgan reservoir under the Soviet program of compensatory stocking in 1986, took its place in the benthic community of the biocenosis and established a stable population.

Currently, M. nipponense have spread to the lower reaches of the Dniester River, successfully reproduce, and their number is constantly growing. The highest density of $M$. nipponense was recorded in the Dniester lagoon $\left(17\right.$ individuals $\left.\cdot \mathrm{m}^{-2}\right)$, the lowest in the Bile Lake (2.2 individuals $-\mathrm{m}^{-2}$ ). Their sex ratio also differed significantly in different areas: from 1: 1 (Bile Lake) to 11: 6 (Dniester lagoon).

The density of $M$. nipponense varied significantly during a day. Thus, at sampling sites in the Dniester and Kuchurgan lagoons, diurnal fluctuations in their abundance a similar dynamics. The maximum number of shrimp was observed at four o'clock in the morning, gradually decreasing to 9 o'clock. In the period from 12 to 24 hours, the density of shrimp was at a minimum, relatively stable level. From 1 o'clock at night there is a gradual increase in the number of shrimp to a maximum. In the Dniester lagoon, the process was more dynamic, and the fluctuations were more significant than in the Kuchurhan lagoon.

The life cycle of $M$. nipponense in the Dniester River basin is synchronized and associated with natural rhythms that occur in their natural habitat.

\section{LITERATURE}

1. Биоразнообразие ракообразных Узбекистана / Мирабдуллаев И. И. и др. // Узбек. биол. журн. 1997. С. 51-52.

2. Буруковский Р. Н. Методика биологического анализа некоторых тропических и субтропических креветок // Промысловые исследования морских беспозвоночных. Москва : ВНИРО, 1992. С. 77-84.

3. Владимиров М. 3. Восточная речная креветка (Macrobrachium nipponense De Haan) - новый элемент гидрофауны Кучурганского водохранилища // Известия АН МССР. 1989. № 1. С. 77-78.

4. Гигиняк Ю. Г. Результаты интродукции субтропической пресноводной креветки Macrobrachium nipponense (De Haan) в водоем-охладитель Березовской ГРЭС (Беларусь) // VII Всероссийская конференция по промысловым беспозвоночным (памяти Б. Г. Иванова), Мурманск, 9-13 окт. 2006 г. : тезисы докл. Москва : ВНИРО, 2006. С. 276-277.

5. Гидрохимические особенности двух контрастных (Дубоссарского и Кучурганского) водохранилищ / Касапова Л. В. и др. // Интегрированное управление бассейном трансграничного Днестра: платформа для сотрудничества и современные вызовы : Междунар. конф., Тирасполь, 26-27 окт. 2017 г. : матер. Тирасполь : Eco-TIRAS, 2017. С. 164-166.

6. Кулеш В. Ф. Перспективы выращивания субтропической креветки Macrobrachium nipponense (De Haan) в водоемах-охладителях ТЭC // 
Биологические ресурсы водоемов в условиях антропогенного воздействия. Киев : Наукова думка, 1985. С. 34-36.

7. Современное состояние популяций чужеродных видов моллюсков в бассейн p. Днестр / Мунжиу О. В. и др. // Геоэкологические и биоэкологические проблемы Северного Причерноморья : V Междунар. науч.практ. конф., 14 ноября 2014 г. : матер. Тирасполь : ПГУ, 2014. С. 179-184.

8. Набиева К. Р. Пресноводные креветки в водоемах Арнасайской системы // Узбек. биол. журн. 1978. № 2. С. 55-57.

9. Нартыш О. М. Молдавская ГРЭС: дела и люди (Исторический очерк). Днестровск : Типар, 1998. 120 с.

10. Определитель пресноводных беспозвоночных России и сопредельных территорий. Ракообразные. Санкт-Петербург : ЗИН РАН, 1995. Т. 2.628 с.

11. Степанок Н. А. Восточная речная креветка рода Macrobrachium в низовье Днестра // Гидробиологический журнал. 2014. Т. 50, № 2. С. 117-120.

12. Филипенко С. И. О появлении пресноводной восточной креветки Macrobrachium nipponense (De Haan, 1849) в Днестре // Sustainable use and protection of animal world diversity. : International Symposium dedicated to 75 th anniversary of professor Andrei Munteanu : proceed. Chișinău, 2014. C. 206-207.

13. Филипенко С. И., Мустя М. В. О первой находке североамериканского краба Rhithropanopeus harrisi tridentata (Maitland, 1874) в Приднестровье // Озёрные экосистемы: биологические процессы, антропогенная трансформация, качество воды : V Междунар. науч. конф., 12-17 сент. 2016 г. : тезисы докл. Минск ; Нарочь: БГУ, 2016. С. 397-398.

14. Шекк П. В., Астафуров Ю. О. Можливість культивування східної субтропічної прісноводної креветки Macrobrachium nipponense (De Haan, 1849) в умовах нижнього Дністра // Сучасні проблеми теоретичної та практичної іхтіології : XII Міжнар. іхтіол. наук.-практ. конф. : матер. Дніпро, 2019. C. $232-235$.

15. Шекк П. В., Астафуров Ю. О. Проблема біологічних інвазій, вселення чужорідних видів на прикладі східної прісноводної креветки Macrobrachium nipponense (De Haan, 1849) // Студентська наукова конференція молодих вчених Одеського державного екологічного університету : збірник матер. Одесса, 2019. № 7. С. 102-103.

16. Cai Y., Ng P. K. L. The freshwater palaemonid prawns of Myanmar (Crustacea: Decapoda: Caridea) // Hydrobiologia. 2002. Vol. 487. P. 59-83.

17. Cai Y., Shokita S. Report on a collection of freshwater shrimps (Crustacea: Decapoda: Caridea) from the Philippines, with descriptions of four new species // Raffles Bulletin of Zoology. 2006. Vol. 54. P. 245-270.

18. Clark P. F., Abdul-Sahib I. M., Al-Asadi M. S. The first record of Eriocheir sinensis H. Milne Edwards, 1853 (Crustacea: Brachyura: Varunidae) from the Basrah Area of Southern Iraq // Aquatic Invasions. 2006. Vol. 1(2). P. 51-54.

19. Kutty M. N. Towards sustainable freshwater prawn aquaculture - lessons from shrimp farming, with special reference to India. Aquaculture Research. 2005. Vol. 36. P. 255-263.

20. Mirabdullaev I. M., Niyazov D. S. Alien decapods (Crustacea) in Uzbekistan // II International Symposium Invasion of alien species in Holarctic (BOROK-2), Borok, Russia, September 27- October 1, 2005 : abstracts. Borok 2005. P. 113114. 
21. The invasion of Macrobrachium nipponense (De Haan, 1849) (Caridea: Palaemonidae) into the Southern Iraqi marshes / Salman S. D. et al. // Aquatic Invasions. 2006. Vol. 1. P. 109-115.

22. Suzuki H., Kusamura T. Reexamination of the diagnostic characters of two freshwater palaemonid prawns, Macrobrachium nipponense (De Haan, 1849) and M. formosense Bate, 1868 (Decapoda, Caridea) from Japan // Crustaceana. 1997. Vol. 70. P. 831-839.

\section{REFERENCES}

1. Myrabdullaev, Y. Y., et al. (1997). Byoraznoobrazye rakoobraznykh Uzbekystana. Uzbek. byol. zhurn., 51-52.

2. Burukovskyi, R. N. (1992). Metodyka byolohycheskoho analyza nekotorbkh tropycheskykh y subtropycheskykh krevetok. Promyslovye issledovaniia morskykh bespozvonochnykh. Moskva: VNYRO, 77-84.

3. Vladymyrov, M. Z. (1989). Vostochnaia rechnaia krevetka (Macrobrachium nipponense De Haan) - novyi element hydrofauny Kuchurhanskoho vodokhranylyshcha. Yzvestyia AN MSSR, 1, 77-78.

4. Hyhyniak, Yu. H. (). Rezultaty yntroduktsyy subtropycheskoi presnovodnoi krevetky Macrobrachium nipponense (De Haan) v vodoem-okhladytel Berezovskoi HRES (Belarus). VII Vserossyiskaia konferentsyia po promыslovыm bespozvonochnыm (pamiaty B. H. Yvanova), Murmansk, 9-13 okt. 2006 h. : tezysы dokl. Moskva : VNYRO, 2006. S. 276-277.

5. Kasapova, L. V., Fylypenko, S. Y., Rudenko, A. K., \& Kalatynskaia, M. A. (2017). Hydrokhymycheskye osobennosty dvukh kontrastnykh (Dubossarskoho y Kuchurhanskoho) vodokhranylyshch. Yntehryrovannoe upravlenye basseinom transhranychnoho Dnestra: platforma dlia sotrudny-chestva y sovremennye vyzovy. Materyaly mezhdunarodnoi konferentsyy, Tyraspol, 26-27 oktiabria $2017 \mathrm{~h}$. Tyraspol: Eco-TIRAS, 164-166.

6. Kulesh, V. F. (1985). Perspektyvy vyrashchyvanyia subtropycheskoi krevetky Macrobrachium nipponense (De Haan) v vodoemakh-okhladyteliakh TES. Byolohycheskye resursy vodoemov $v$ uslovyiakh antropohennoho vozdeistvyia. Kyev: Naukova dumka, 34-36.

7. Munzhyu, O. V., Toderash, Y. K., Shubernetskyi, Y. V., Railian, N., \& Fylypenko, S. Y. (2014). Sovremennoe sostoianye populiatsyi chuzherodnykh vidov molliuskov v bassein r. Dnestr. Heoekolohycheskie y byoekolohycheskie problem Severnoho Prychernomoria. Materyaly V Mezhdunarodnoi nauchno praktycheskoi konferentsyy, 14 noiabria 2014 h. Tyraspol: PHU, 179-184.

8. Nabyeva, K. R. (1978). Presnovodnye krevetki v vodoemakh Arnasaiskoi systemy. Uzbek. byol. zhurn., 2, 55-57.

9. Nartysh, O. M. (1998). Moldavskaia HRES: dela y liudy (Istorycheskyi ocherk). Dnestrovsk: Typar.

10. Opredelytel presnovodnykh bespozvonochnykh Rossyy y sopredelnykh terrytoryi. Rakoobraznye. (Vol. 2). (1995). Sankt-Peterburh: ZYN RAN.

11. Stepanok, N. A. (2014). Vostochnaia rechnaia krevetka roda Macrobrachium v nyzove Dnestra. Hydrobyolohycheskyi zhurnal, 50(2), 117-120.

12. Fylypenko, S. Y. (2014). O poiavlenyy presnovodnoi vostochnoi krevetky Macrobrachium nipponense (De Haan, 1849) v Dnestre. Sustainable use and 
protection of animal world diversity: International Symposium dedicated to 75 th anniversary of professor Andrei Munteanu: proceed. Chișinău, 206-207.

13. Fylypenko, S. Y., \& Mustia, M. V. (2016). O pervoi nakhodke severoamerykanskoho kraba Rhithropanopeus harrisi tridentata (Maitland, 1874) v Prydnestrove. Oziornye ekosistemy: byolohycheskye protsessy, antropohennaia transformatsyia, kachestvo vody: Tez. dokl. V Mezhdunar. nauch. konf., 12-17 sentiabria 2016 h. Mynsk; Naroch: BHU, 397-398.

14. Shekk, P. V., \& Astafurov, Yu. O. (2019). Mozhlyvict kultyvuvannia skhidnoi subtropichnoi prisnovodnoi krevetky Macrobrachium nipponense (De Haan 1849) v umovakh nyzhnoho Dnistra. Suchasni problemy teoretychnoi ta praktychnoi ikhtiolohii: XII Mizhnar. ikhtiol. nauk.-prakt. konf.: mater. Dnipro, 232-235.

15. Shekk, P. V., \& Astafurov, Yu. O. (2019). Problema biolohichnykh invazii, vselennia chuzhoridnykh vydiv na prykladi skhidnoi prisnovodnoi krevetky Macrobrachium nipponense (De Haan 1849). Studentska naukova konferentsiia molodykh vchenykh Odeskoho derzhavnoho ekolohichnoho universytetu: zbirnyk mater. (Vol. 7). Odessa, 102-103.

16. Cai, Y., \& Ng, P. K. L. (2002). The freshwater palaemonid prawns of Myanmar (Crustacea: Decapoda: Caridea). Hydrobiologia, 487, 59-83.

17. Cai, Y., \& Shokita, S. (2006). Report on a collection of freshwater shrimps (Crustacea: Decapoda: Caridea) from the Philippines, with descriptions of four new species. Raffles Bulletin of Zoology, 54, 245-270.

18. Clark, P. F., Abdul-Sahib, I. M., \& Al-Asadi, M. S. (2006). The first record of Eriocheir sinensis H. Milne Edwards, 1853 (Crustacea: Brachyura: Varunidae) from the Basrah Area of Southern Iraq. Aquatic Invasions, 1(2), 51-54.

19. Kutty,, M. N. (2005). Towards sustainable freshwater prawn aquaculture - lessons from shrimp farming, with special reference to India. Aquaculture Research, 36, 255-263.

20. Mirabdullaev, I. M., \& Niyazov, D. S. (2005). Alien decapods (Crustacea) in Uzbekistan. II International Symposium Invasion of alien species in Holarctic (BOROK-2), Borok, Russia, September 27 - October 1, 2005 : abstracts. Borok, 113-114.

21. Salman, S. D., Page, T. J., Naser, M. D., \& Yasser, A. G. (2006). The invasion of Macrobrachium nipponense (De Haan, 1849) (Caridea: Palaemonidae) into the Southern Iraqi marshes. Aquatic Invasions, 1, 109-115.

22. Suzuki, H., \& Kusamura, T. (1997). Reexamination of the diagnostic characters of two freshwater palaemonid prawns, Macrobrachium nipponense (De Haan, 1849) and M. formosense Bate, 1868 (Decapoda, Caridea) from Japan. Crustaceana, 70, 831-839. 